\title{
Investigating Capital Structure, Performance and Stock Price in U.S. Technology Firms: Panel Data Analysis
}

\author{
May Elewa \\ Assistant Professor of Accounting, School of Business Administration \\ Ahram Canadian University ACU, Egypt \\ E-mail: mayelewa@acu.edu.eg
}

Received: February 21, 2021

Accepted: March 12, 2021

Published: March 29, 2021

doi: 10.5296/ijafr.v11i1.18334

URL: https://doi.org/10.5296/ijafr.v11i1.18334

\begin{abstract}
The study investigates the relationship among liquidity substituted by current ratio CR., capital structure proxied via debt to equity $\mathrm{D} / \mathrm{E}$ ratio, the financial performance represented by return on equity ROE plus return on assets ROA, and stock price SP. Technology firms listed on the NASDAQ 30 index in America, which use generally accepted accounting principles (GAAP), are considered. Data is from the Standard and Poor S\&P 500 database. The data set contains 672 observations with $n=12$. Data collected is of technology firms which operate in cash, have quarterly reports from 2005-2018, have no missing data, and are not disqualified during the study period. The study applies the pooled regression, the fixed effect, and the random effect techniques and the panel data analysis. The findings indicate a relationship between capital structure, financial performance, and stock price. This paper benefits internal and external stakeholders and may enhance business operations leading to higher financial performance.
\end{abstract}

Keywords: The USA, Technology firms, Liquidity, Capital structure, Financial performance, Stock price

\section{Introduction}

Measuring the firm financial performance has acquired substantial consideration in developed and developing countries. Profitability is a primary measurement of how well a firm operates its resources to produce income. The study uses profitability to measure the technology firm's financial health. Certain variables are associated with technology firm profitability, such as liquidity (Nazish and Shehla 2017; Kimondo et al. 2016; Nassirzadeh and Rostami 2010; Ehiedu 2014) and capital structure (Devi and Devi 2014; Khan 2012; Umar et al. 2012; Basit and Hassan 2017; Ahmad et al. 2015). The (Zeitun and Tian 2007) study explains the close 


\section{MlMacrothink}

International Journal of Accounting and Financial Reporting

ISSN 2162-3082

2021, Vol. 11, No. 1

link of capital structure to firm financial performance. The research on hand supports this idea.

The American business environment is dynamic, diverse, competitive, and very demanding due to the business environment's rapid changes. Also, the firms are often constantly reforming, which results in structural and policy modifications. Decision-makers have an increased demand for new and updated information on a more timely basis. These are only a few justifications that substantiate the importance of this study.

The contribution is a result of the investigation of the connection of capital structure and liquidity with technology company financial performance and the relationship of this financial performance on the stock price. Thus, it is evident that this contribution is twofold. First, the study undertakes an empirical evaluation to determine if capital structure and liquidity have any relationship with technology firm financial performance. What if the results indicate that both of these independent variables connect with technology firms' financial performance? In that case, it is worth going on investigating further to determine which factor has more impact. Thus, it would include two (capital structure and liquidity) elements in the evaluation; this allows comparison to increase accuracy.

Second, the study empirically evaluates the relationship between CR., D/E ratio, ROA, ROE, and SP of technology firms. The paper's primary purpose is to identify the type of association that occurs with the internal and external business environment. The study investigates if the firm's health and quality of operation are essential to its survival and success in the market.

This study is limited to the relationship between CR, D/E ratio, ROA, ROE, and SP of technology firms. The research on hand evaluates only the firms that meet all of the following citeria: active, publicly listed firms from the NASDAQ 30 index, USA technology firms from the technology and innovation sector and that use the generally accepted accounting principles (GAAP). The study chooses the technology firms for evaluation according to the following criteria: operate in cash, have quarterly reports from 2005-2018, have no missing data, and have not been disqualified at any time during the study period.

This research's primary importance is that it adds to the prior research work done in the American technology and innovation sector related to liquidity and capital structure decisions with financial performance and decisions related to technology firms' financial performance and stock prices. Findings indicate a relationship between capital structure, technology firm financial performance, and stock price. This study is a tool for interested parties to maximize their wealth.

The rest of this paper proceeds as follows: The second section includes the literature review and hypothesis development. The third section consists of the research methodology, statistical tests, results, and findings. The fourth section is the conclusion, with recommendations and presentation of future studies. 


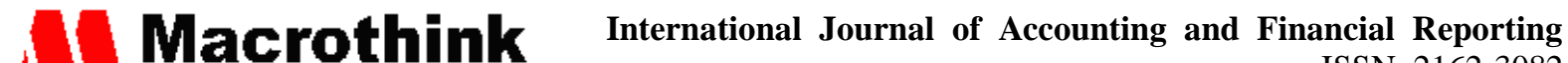 ISSN 2162-3082 2021, Vol. 11, No. 1}

\section{Literature Review and Hypotheses Development}

This part demonstrates what other researchers have observed and found that relate to the topic. Various theories clarify the existence of firms and the rationale for the differences in their structure and performance. The trade-off approach entails a stable method of funding related assessments based on an object capital structure. In contrast, pecking order theory permits the company's operation to put the best capital structure on any particular occasion. The trade-off theory generated by (Modigliani and Miller 1958) assumes that by applying trade-off concerning the costs and benefits of equity and debt, the most advantageous capital structures will appear.

(Durand and Coeurderoy 2001; Zeitun et al. 2017) support pecking order theory. Consistent with the pecking order theory, companies select capitals in line with the following sequence: internal finance, debt, and equity. (Peyravan 2019) find that dual-holders of the firm's debt and equity are more likely to participate in firms with low financial reporting quality FRQ.

Thus, the pecking order theory encourages internal financing through retained earnings. If this is not feasible, the firm can resort to debt financing; if this option is not possible, the firm resorts to financing itself by issuing new equity. The pecking order in financing is an essential indication for the public of how the firm is operating. (Mudambi and Nicosia 1998) and (Tzelepis and Skuras 2004) provide practical evidence that confirms this discussion.

A healthy firm can cover itself from the inside. A firm with confident management can finance itself using debt. An unhealthy firm seeks to issue new stocks in the market to be able to finance itself. Thus, prosperous firms are more likely to fund themselves by themselves or by debt financing. According to (Weber and Yang 2020), firms tend to finance themselves using debt more than equity when they have high market values bound by costly regulation.

The economies of scale theory describe the importance of large firm size over small firm size. (Padron et al. 2005) support the economies of scale theory that assumes the firm's size and firm profitability are related. This relationship confirms that large-size firms can: negotiate with suppliers and customers, maintain higher prices than the competitive range, compete with their counterparts, generate and maintain strategic diversification.

This literature review includes studies undertaken in Pakistan, Jordan, Kenya, Romania, India, Iran, Rwanda, Sir Lanka, Vietnam, Macedonia, Turkey, Nigeria, Bahrain, Bangladesh, Ghana, USA, and the Netherlands. The different industries studied were manufacturing, engineering, automobile manufacturing and assembling, construction material, consumer goods, food and beverage, cement, pharmaceutical, textile, healthcare, energy, and chemical sectors.

Research studies (Devi and Devi 2014; Khan 2012; Umar et al. 2012; Basit and Hassan 2017; Ahmad et al. 2015) inspect the relationship of capital structure with the financial performance of firms operating in the Pakistan business environment and listed in the Karachi Stock Exchange (KSE). Secondary data from financial statements are collected.

(Devi and Devi 2014) collected data from fifty listed companies during 2006-2012. The study applied the ordinary least square regression. Outcomes imply a positive connection of 
financial leverage represented by fixed interest-bearing funds and firm size represented by sales turnover with healthy profitability. A negative link to the summation of reinvested profit, the new capital, and long-term debt financing with firm profitability exists.

(Khan 2012) gathered data from thirty-six engineering firms 2003-2009 and employed Pooled Ordinary Least Square regression. Findings show a significant negative association of total debt to total assets (TDTA) also short term debt to total assets (STDTA) with the gross profit margin (GPM), Tobin's Q, and return on assets (ROA). Findings also show the relationship between financial leverage and return on equity (ROE) is negative and insignificant. The number of asset resources, ROA, and GPM has an irrelevant relationship. The number of asset resources and Tobin's $Q$ has a negative and significant link.

(Umar et al. 2012) obtained data from one hundred firms during 2006-2009. The study applies the exponential generalized least square regression. Findings show Long Term Liabilities to Total Asset, Total Liabilities to Total Assets, plus Current Liabilities to Total Asset have a negative influence on Return on Assets, Earnings before Interest and Taxes, Net Profit Margin also Earning per Share. Negative connection of Current Liabilities to Total Asset with Price Earnings ratio exists. A positive association of Long Term Liabilities to Total Asset with Price Earnings ratio exists. The connection of Total Liabilities to Total Assets with the Price Earnings ratio is insignificant. Outcomes also show that ROE has a minor influence on Total Liabilities to Total Assets and Current Liabilities to Total Assets. Nevertheless, a positive connection of Long Term Liabilities to Total Asset with ROE occurs.

(Basit and Hassan 2017) got data from a sample of fifty firms from 2010-2014, equivalent to 250 firms-years observation. The study applies the multiple linear regressions and Pearson correlation coefficient. Outcomes indicate EPS, ROE, and ROA are significantly correlated to $\mathrm{D} / \mathrm{E}$ ratio, while the $\mathrm{D} / \mathrm{E}$ ratio substantially affects size and $\mathrm{ROA}$.

(Ahmad et al. 2015) attained data from eighteen cement manufacturing companies during 2005-2010 and applies an Ordinary Least Square model. Outcomes reveal financial leverage has a significant opposite influence on (ROA).

Research studies (Appiadjei 2014; MacCarthy and Ahulu 2019) explore the relationship of capital structure with publicly registered firms' financial performance of the Ghana Stock Exchange (GSE) and operating in Ghana business environment. Secondary data off financial statements are acquired.

(Appiadjei 2014) acquired data from a sample of thirty-five listed companies during 2004-2008. The study uses three multiple regression models. Findings show a meaningful positive connection with short-term debt STD and total equity TE, return on equity ROE, return on total capital ROTC, and return on assets ROA. There is a substantial negative link with long term debt LTD, ROE, ROA, and TE.

(MacCarthy and Ahulu 2019) gathered data from seventeen listed firms from 2009- 2018. The study uses panel data regression. Findings show a significant negative relationship between the total debt (TD) ratio and the short-term debt (STD) ratio with return on equity ROE. 


\section{Mll Macrothink}

International Journal of Accounting and Financial Reporting

ISSN 2162-3082

2021, Vol. 11, No. 1

Studies (Mwangi et al. 2014; Tharmila and Arulvel 2013; Cuong et al. 2018; Khalaf 2013; Asiri and Hameed 2014; Cole et al. 2015; Mauwa et al. 2016) investigate the relationship of capital structure with financial performance. Financial statements are the source of secondary data obtained.

(Mwangi et al. 2014) obtained data from forty-two non-financial firms publicly registered in Nairobi Securities Exchange NSE in Kenya during 2006-2012. The research uses panel data analysis and Feasible Generalised Least Square regression. Findings show financial leverage held a significant negative connection to (ROA) and (ROE).

(Tharmila and Arulvel 2013) collected data from thirty publicly registered companies off Colombo Stock Exchange (CSE) Sri Lanka 2007-2011. Tharmila and Arulvel use correlation analysis. Findings show the D/E ratio connection with return on capital employed, ROE, and NP ratio is negative.

(Cuong et al. 2018) investigate the internal factors affecting financial performance from data of thirty publicly registered construction-material companies off the Vietnam stock market. The study uses regression analysis. The outcomes reveal accounts receivable management, capital structure, firm size, capitalization expenditure, and business risk have a positive connection with financial performance.

(Khalaf 2013) gathered data from forty-five publicly registered Jordanian manufacturing companies off the Amman Stock Exchange in 2005-2009. The study applies multiple regression analysis. Findings show a negative and minor connection between Long Term Debt to Total Assets LTDTA and Short Term Debt to Total Assets STDTA, and Profit Margin PM and Return on Asset ROA. Furthermore, findings show a positive connection with Total Debt to Equity TDE to ROA and a negative connection with Profit Margin PM. LTDTA is significant using PM, whereas STDTA is significant using ROA.

(Asiri and Hameed 2014) measure the financial ratios ability to explain the firm worth using the market to book ratio or price-earnings ratio. Asiri and Hameed got figures for companies publicly registered in Bahrain Bourse in Bahrain from 1995-2013. Findings show that return on assets, then financial leverage followed by beta, are determinant factors. Furthermore, results revealed that the firm size measured by Tobin's Q ratio and total assets substantially affects its market value.

(Cole et al. 2015) attained data for thirty U.S. firms in the Industrial, Healthcare, and Energy Sectors from 2004 to 2013, equivalent to 300 firm-year observations. The study uses simple regression. Findings show that capital structure and financial performance differ from one sector to another and from one variable to another. The long term liabilities to total assets ratio negatively impacts ROA also the operating margin included in all three of the sectors used in this study.

(Mauwa et al. 2016) acquired data from six publicly registered firms off Rwanda Stock Exchange (RSE) Rwanda for 2014. The study uses correlation analysis and regression analysis. Outcomes show leverage, and ROA have negative connection. Also, results reveal a negative link between leverage and ROE. 


\section{Mll Macrothink}

International Journal of Accounting and Financial Reporting

ISSN 2162-3082

2021, Vol. 11, No. 1

(Omondi and Muturi 2013) obtained data from a sample of twenty-nine non-financial institutions during 2006-2012. The study uses mean and standard deviation and Pearson correlation and multiple regression. Outcomes show that D/E and ROA have a significant positive connection. Also, findings show that current assets/current liabilities and ROA have a meaningful positive relationship. Furthermore, results show that company size and ROA have a significant positive connection. Finally, findings show that company age and ROA have a significant positive connection.

(Dioha et al. 2018) studied the link of firm age, sales growth, firm size, leverage, and liquidity on return on sales (ROS). Data was collected from eighteen publicly registered consumer goods firms off the Nigerian Stock Exchange (NSE) in Nigeria 2011-2016. The study uses multiple regression analysis and fixed and random effects models. Findings show a significant connection of leverage, sales growth, and firm size with ROS. However, no association exists between liquidity and firm age with ROS.

(Navleen and Jasmindeep 2016) study the relationship of firm-specific factors represented by financial leverage, the tangibility of assets, firm size, liquidity, growth of the firm, D/E ratio, total assets turnover ratio, inventory turnover ratio, debtor's turnover ratio, average payment period, with profitability represented by ROA. The study gathered data for all the publically registered automobile firms Bombay Stock Exchange (BSE) India 2003-2013. Navleen and Jasmindeep 2016 applied correlation analysis, step-wise regression analysis, and multiple regression analysis. Findings show a significant influence on firm growth, the liquidity position of the firm, D/E ratio, inventory turnover ratio, and average payment period on ROA.

(Borhan et al. 2014) examine the impact of current ratio CR, quick ratio QR, debt ratio DR, net profit margin NPM, debt to equity $\mathrm{D} / \mathrm{E}$ ratio, and operating profit margin OPM on revenue. The study got data for the chemical company LyondellBasell Industries (LYB), the Netherlands, during 2004-2011, quarterly. The study applied a multiple regression model. Findings show a positive connection with NPM, QR, CR, and DR to revenue, although a negative connection exists between OPM and D/E ratio. Among the six ratios, CR, DR, and NPM show the highest significant impact on financial performance (revenue).

Research studies (Nazish and Shehla 2017; Kimondo et al. 2016; Nassirzadeh and Rostami 2010; Ehiedu 2014) investigate firm liquidity with financial performance or profitability. Secondary data from financial statements are collected.

(Nazish and Shehla 2017) attained data from a sample of fifty publicly registered Pakistani non-financial institutions Karachi Stock Exchange 2007 - 2011. Nazish and Shehla applied regression and correlation analysis. Findings show a significant negative connection between the cash gap and return on assets ROA and net operating income. Results show the current ratio has a significant positive relationship with net operating income and ROA. Findings also show a significant positive association with the log of total assets and sales $\log$ with net operating income and ROA. 


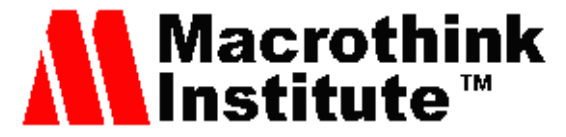

International Journal of Accounting and Financial Reporting

ISSN 2162-3082

(Kimondo et al. 2016) acquired data from thirty-nine listed non-financial companies in the Nairobi Stock Exchange NSE in Kenya from 2010 to 2014. The study applied correlation and regression analysis. Findings established a significant positive connection of quick ratio, current ratio, and cash ratio with ROA. Control variables used were firm size, sales growth, and firm leverage represented by DR.

(Nassirzadeh and Rostami 2010) obtained data for a sample of one hundred eight companies listed in Tehran Stock Exchange in Iran 2002-2010. Nassirzadeh and Rostami used correlation analysis, multivariable regression, and panel data. Outcomes indicate a weak correlation between the liquid and current ratios, the cash conversion cycle index, the net liquidity balance index, and a comprehensive liquidity index. Outcomes indicate the substantial connection of all traditional and modern indices of profitability and liquidity represented by ROA, ROE, and net profit margin NPM ratio.

In (Ehiedu 2014), the population consists of publicly listed companies in the Nigerian Stock Exchange (NSE) 2007-2011. However, the study draws its sample population from two selected companies. Ehiedu applied a simple correlation analysis. Findings indicate no certain major correlation between ROA and Acid-test ratio, a substantial positive correlation between ROA and CR, and no significant positive correlation with return on capital employed and ROA exists.

(Hann et al. 2020) supports the more financial reporting is informative about productivity, the better the efficiency of resource allocation; hence, real effects at the macro level are generated.

(Utami and Darmawan 2019) studied the connection of D/E ratio, ROA, ROE, EPS, and market value-added with stock prices SP of publicly registered manufacturing companies of the Indonesian Sharia Stock Index. Utami and Darmawan gathered data from a sample of fifty-three companies during 2012-2016, equivalent to 265 firm-year observations. The study used panel data analysis. Findings prove, EPS and market value-added have a positive effect on SP, but different results for the variables D/E ratio, ROA, and ROE partially have no impact on SP.

(Kim et al. 2020) state that the increase in stock price and the decrease in the disclosure lead to increases in the firm's market share, cost of equity, and market-to-book ratio that indicates for the sake of product-market gains, managers are willing to sacrifice capital market gains.

Thus, this research proposes a relationship between liquidity, capital structure, financial performance, and stock price from the above literature review. From here, we develop our hypotheses to test:

H1: liquidity holds a significant connection with financial performance.

H2: capital structure holds a significant connection with financial performance.

H3: firm financial performance holds a significant connection with the stock price. 


\section{Macrothink \\ International Journal of Accounting and Financial Reporting \\ ISSN 2162-3082 \\ 2021, Vol. 11, No. 1}

\section{Research Methodology}

This study investigates the relationship between the liquidity represented by $\mathrm{CR}$, the capital structure represented by D/E ratio, the financial performance represented by ROA and ROE, and the stock price SP. The study focuses on the publicly listed technology firms adopting GAAP, as shown in table 1 in order according to the market cap.

Table 1. Publicly active NASDAQ listed technology firms adopting FASB

\begin{tabular}{cccc}
\hline & Stock symbol & Name & $\begin{array}{c}\text { Market Cap } \\
\text { (billion) } \$\end{array}$ \\
\hline 1 & MSFT & Microsoft & 1136.2 \\
\hline 2 & AAPL & Apple & 1021.6 \\
\hline 3 & GOOGL & Alphabet & 892.4 \\
\hline 4 & CSCO & Cisco & 222.6 \\
\hline 5 & INTC & Intel & 222.2 \\
\hline 6 & ADBE & Adobe & 150.3 \\
\hline 7 & TXN & Texas Instruments & 125.3 \\
\hline 8 & NVDA & Nvidia & 110.4 \\
\hline 9 & QCOM & Qualcomm & 99.7 \\
\hline 10 & INTU & Intuit & 80.6 \\
\hline 11 & ADP & ADP & 79.8 \\
\hline 12 & FISV & Fiserv & 79.4 \\
\hline \multicolumn{5}{c}{ Order according to the market cap }
\end{tabular}

Variables definition:

Current ratio $=$ short term assets/short term liabilities

Return on assets $(\mathrm{ROA})=$ net income/total assets

Debt to equity $(\mathrm{D} / \mathrm{E})$ ratio $=$ total liability/owner equity

Return on equity $(\mathrm{ROE})=$ net income/shareholder equity

Stock Price S.P.

The study collects data on all study variables from Standard and Poor's S\&P 500 index. The record has 672 observations, $n=12$, in the USA. The data collected comprises 12 active companies in the technology and innovation sector, listed on the NASDAQ 30 index, operating in cash, have quarterly reports from 2005-2018, have no missing data, not disqualified at any time during the study period.

\section{Empirical Results}

The regression analysis is a numerical technique that permits a scholar to evaluate the linear connection among variables. The regression model consists of the $\mathrm{X}$ independent variable and Y dependent variable. 


\section{Mll Macrothink}

International Journal of Accounting and Financial Reporting

The straight line joining $X$ and $Y$ is algebraically expressed as:

$$
Y=a+b X
$$

intercept $a$ and slope is $b$.

$$
Y=a+b X=a+b(0)=a+0=a
$$

where the intercept for the line is $a$.

The study applied the pooled regression, the fixed effect, and the random effect techniques with the panel data analysis based on the following equation:

$$
y_{i t}=\alpha_{o i}+\beta_{i t} X_{i t}+E_{i t}
$$

$\mathrm{y}_{\mathrm{it}}$ : The dependent variable, attributed to $\mathrm{i}$ units, over the period $\mathrm{t}$

$\alpha_{\mathrm{oi}}$ : Represent the fixed term for the sample $\mathrm{i}$

$\beta_{\mathrm{it}} \mathrm{X}_{\mathrm{it}}$ : Independent variable and its slope

$\mathrm{E}_{\mathrm{it}}:$ random error

The following three models were used to analyze the panel data on hand:

1- Pooled model

2- Fixed Effects Model

3- Random Effects Model

The study applies five steps to determine which model most appropriately represents the impact of the independent variables liquidity and capital structure on the dependent performance variable and the performance variable that is independent of the dependent Stock Price SP variable. These five steps are:

1- The Pooled Model

2- The Fixed Effect Model

3- The F-Test for the comparison of the results of the Pooled Model and the Fixed Effect Model

4- The Random Effect Model

5- The Hausman test compares the Random Effects Model and the Fixed Effect Model results to confirm the most suitable application.

The study makes this five-step analysis when:

First, the firm financial performance is the dependent variable, and the independent variables are capital structure and liquidity.

Second: the firm financial performance is the independent variable, and the dependent variable is stock price SP. 


\section{Macrothink \\ International Journal of Accounting and Financial Reporting

H1: Liquidity holds a significant connection with financial performance.

Table 2-1. Descriptive Statistics for ROA and CR

\begin{tabular}{lcc}
\hline & ROA & CR \\
\hline Median & 0.029543 & 2.556748 \\
\hline Kurtosis & 12.62614 & 9.160552 \\
\hline
\end{tabular}

Source: E-views 9 output program

Table 2-1 specifies that the median for dependent variable $\mathrm{ROA}=0.029$ and the median for the independent variable $\mathrm{CR}=2.55$. Results also indicate Kurtosis for the dependent variable $\mathrm{ROA}=12.62$ and Kurtosis for the independent variable $\mathrm{CR}=9.16$.

Table 2-2. Descriptive Statistics for ROE and CR

\begin{tabular}{lll}
\hline & ROE & CR \\
\hline Median & 0.123867 & 2.556748 \\
\hline Kurtosis & 396.9330 & 9.160552 \\
\hline
\end{tabular}

Source: E-views 9 output program

Table 2-2 displays the median for dependent variable $\mathrm{ROE}=0.12$ and the median for the independent variable $\mathrm{CR}=2.55$. Results also indicate Kurtosis for the dependent variable $\mathrm{ROE}=396$ and Kurtosis for the independent variable $\mathrm{CR}=9.16$.

Table 3-1. Correlation Analysis for ROA and C.R.

\begin{tabular}{cll}
\hline Correlation t-Statistic Probability & ROA & CR \\
\hline CR & 0.188104 & 1.000000 \\
\hline
\end{tabular}

Source: E-views 9 output program

Table 3-1 demonstrates a weak direct link of dependent variable ROA and independent variable $C R$ because $R=0.18$. The $p<0.05$ means a significant connection exists with $R O A$ and CR.

Table 3-2. Correlation Analysis for ROE and C.R.

\begin{tabular}{ccc}
\hline Correlation t-Statistic Probability & ROE & CR \\
\hline CR & -0.049083 & 1.000000 \\
\hline
\end{tabular}

Source: E-views 9 output program

Table 3-2 displays a weak inverse association of the dependent variable ROE with the independent variable $C R$ because of $R=-0.04$. The $p>0.05$ means the significance of $R O E$ with $\mathrm{CR}$ does not exist.

The study performed The Ols Regression test using three methods:

- Common Effect Model or Pooled Least Square (PLS). 
- $\quad$ Fixed Effect Model (FE).

- Random Effect Model (RE).

Hausman test is a numerical check to identify the best to use, the Fixed Effect or Random Effect model.

- If (p>0.05) Random Effect Model (RE) applied.

- If ( $\mathrm{p}<0.05)$ select Fixed Effect Model (FE)

Table 4-1. The Ols Regression Hausman test for ROA and C.R.

\begin{tabular}{lccc}
\hline Test Summary & Chi-Sq. Statistic & Chi-Sq. d.f. & Prob. \\
\hline Cross-section random & 0.253115 & 1 & 0.6149 \\
\hline
\end{tabular}

Source: E-views 9 output program

Table 4-1 illustrates the Hausman test of prob. $=0.6149$ and $p>0.05$. Thus, the most appropriate Regression Model to apply in this case is the RE Model.

Table 4-1-1. The Ols Regression Hausman test for ROA and C.R.

\begin{tabular}{ll}
\hline Cross-section random effects - R-squared & 0.023882 \\
\hline Cross-section fixed - R-squared & 0.156917 \\
\hline
\end{tabular}

Source: E-views 9 output program

However, Table 4-1-1 shows $\mathrm{R}^{2}=0.02$ in the Cross-section random effects indicating a weak relationship. Thus, the regression analysis chooses the Fixed Effect model because of the higher value of $\mathrm{R}^{2} 0.16=16 \%$.

Table 4-2. The Ols Regression Hausman test for ROE and C.R.

\begin{tabular}{lccc}
\hline Test Summary & Chi-Sq. Statistic & Chi-Sq. d.f. & Prob. \\
\hline Cross-section random & 6.991374 & 1 & 0.0082 \\
\hline
\end{tabular}

Source: E-views 9 output program

Table 4-2 indicates the outcome for the Hausman test of a prob. $=0.0082$ and $\mathrm{p}<0.05$. Thus, the most appropriate Regression Model to apply in this case is the FE Model.

The FE Regression analysis perceives that the independent variables' connection and the dependent variable are identical for all Panel Models Estimation.

Table 5-1. Fixed Effect Model (FE) for ROA and C.R.

\begin{tabular}{lllll}
\hline Variable & Coefficient & Std. Error & t-Statistic & Prob. \\
\hline $\mathrm{C}$ & 0.022263 & 0.002626 & 8.478943 & 0.0000 \\
\hline $\mathrm{CR}$ & 0.003276 & 0.000841 & 3.898226 & 0.0001 \\
\hline
\end{tabular}

Effects Specification 
Cross-section fixed (dummy variables)

R-squared 0.156917

Prob(F-statistic) 0.000000

Source: E-views 9 output program

Table 5-1 indicates:

- There is an intermediate direct relationship between the variables of the model as a whole because $\mathrm{R}=\sqrt{ } 0.156917=0.39$

- The FE Regression Model is as follows:

$$
\begin{aligned}
& \mathrm{ROA}=\mathrm{C}(1)+\mathrm{C}(2) * \mathrm{CR}+[\mathrm{CX}=\mathrm{F}] \\
& \mathrm{ROA}=0.0222+0.00327 * \mathrm{CR}+[\mathrm{CX}=\mathrm{F}]
\end{aligned}
$$

- The significance of the independent variable $\mathrm{CR}$ is prob=0.0001 $<0.05$, which means $\mathrm{H} 0$ is accepted, and $\mathrm{H} 1$ is rejected.

H0: numerically substantial independent variables

H1: numerically insignificant independent variables

- Degree of significance regression model is (Prob F-statistic $=0.00<0.05$ ). Thus, the model is numerically substantial (H0 is accepted, and $\mathrm{H} 1$ is rejected).

H0: regression analysis substantial

H1: regression analysis insignificant

- The coefficient of determination R-squared is approx.16\% indicates that $16 \%$ of the ROA changes result from the change in the CR. The remaining $84 \%$ of the dependent variable changes result from other variables not included in the estimated model.

Table 5-2. Fixed Effect Model (FE) for ROE and C.R.

\begin{tabular}{lcccc}
\hline Variable & Coefficient & Std. Error & t-Statistic & Prob. \\
\hline $\mathrm{C}$ & 0.085817 & 0.024675 & 3.477926 & 0.0005 \\
\hline $\mathrm{CR}$ & 0.016175 & 0.007898 & 2.047891 & 0.0410 \\
\hline
\end{tabular}

Effects Specification

Cross-section fixed (dummy variables)

\begin{tabular}{ll}
\hline R-squared & 0.063870 \\
\hline Prob(F-statistic) & 0.000016 \\
\hline
\end{tabular}

Source: E-views 9 output program

Table 5-2 indicates:

- A weak direct association exists with the variables of the model as a whole. This is because $\mathrm{R}=\sqrt{ } 0.063870=0.25$. 
- The FE Regression Model is as follows:

$$
\begin{aligned}
& \mathrm{ROE}=\mathrm{C}(1)+\mathrm{C}(2) * \mathrm{CR}+[\mathrm{CX}=\mathrm{F}] \\
& \mathrm{ROE}=0.0858+0.0161 * \mathrm{CR}+[\mathrm{CX}=\mathrm{F}]
\end{aligned}
$$

- The significance of independent variable CR prob. $=0.04<0.05$. Thus, H0 is accepted, and $\mathrm{H} 1$ is rejected.

H0: numerically substantial independent variables

H1: numerically insignificant independent variables

- Degree of significance regression model is (Prob F-statistic $=0.00<0.05$ ). Thus, the model is numerically substantial (H0 is accepted and $\mathrm{H} 1$ is rejected).

H0: substantial regression analysis

H1: insignificant regression analysis

- The coefficient of determination is R-squared $=6 \%$ indicates that $6 \%$ of the (ROE) changes result from the CR change. The remaining $94 \%$ of other variables are not considered in the estimated model.

The Jarque-Bera is a statistical test used to determine if there is a normal distribution of the series or not. This test measures the kurtosis variance and the series's skewness with those of the normal distribution.

Residuals normal distribution hypothesis is:

H0: Resd. are normally distributed.

H1: Resd. are not normally distributed.

Table 6-1. Jarque-Bera Test of Normality for ROA and C.R.

\begin{tabular}{ll}
\hline Skewness & 1.587957 \\
\hline Kurtosis & 15.78312 \\
\hline Probability & 0.000000 \\
\hline
\end{tabular}

Source: E-views 9 output program

Accordingly, table 6-1 indicates probability $=0.00$. So, $\mathrm{H} 1$ is accepted, and $\mathrm{H} 0$ is rejected.

Table 6-2. Jarque-Bera Test of Normality for ROE and C.R.

\begin{tabular}{ll}
\hline Skewness & -17.29284 \\
\hline Kurtosis & 397.1833 \\
\hline Probability & 0.000000 \\
\hline
\end{tabular}

Source: E-views 9 output program

Table 6-2 specifies probability $=0.00, \mathrm{H} 1$ is accepted, and $\mathrm{H} 0$ is rejected. 


\section{Ml Macrothink \\ International Journal of Accounting and Financial Reporting \\ ISSN 2162-3082 \\ 2021, Vol. 11, No. 1}

According to the results, findings indicate we accepted H1 (liquidity has a significant connection with the firm's financial performance) then reject the null hypothesis.

H2: capital structure holds a significant connection with financial performance.

Table 7-1. Descriptive Statistics for ROA and D/E

\begin{tabular}{lcc}
\hline & ROA & D/E \\
\hline Median & 0.029543 & 0.559787 \\
\hline Kurtosis & 12.62614 & 85.88320 \\
\hline
\end{tabular}

Source: E-views 9 output program

Table 7-1 indicates the median for the dependent variable ROA is 0.029 , and the median for the independent variable $\mathrm{D} / \mathrm{E}$ is 0.55 . The result of Kurtosis for ROA is 12.62 , and $\mathrm{D} / \mathrm{E}$ is 85.88 .

Table 7-2. Descriptive Statistics for ROE and D/E

\begin{tabular}{lcc}
\hline & ROE & D/E \\
\hline Median & 0.123867 & 0.559787 \\
\hline Kurtosis & 396.9330 & 85.88320 \\
\hline
\end{tabular}

Source: E-views 9 output program

Table 7-2 indicates the median for dependent variable ROE is 0.12 , and the median for the independent variable D/E is 0.55. The result of Kurtosis for ROE is 396, and D/E is 85.88.

Table 8-1. Correlation Analysis for ROA and D/E

\begin{tabular}{lcc}
\hline Correlation t-Statistic Probability & ROA & D/E \\
\hline D/E & -0.221147 & 1.000000 \\
\hline
\end{tabular}

Source: E-views 9 output program

Table 8-1 indicates correlation analysis shows a weak inverse association of dependent variable ROA with independent variable $\mathrm{D} / \mathrm{E}$ because of $\mathrm{R}=-0.221$. The $\mathrm{p}<0.05$ means a significant connection exists between ROA \& D/

Table 8-2. Correlation Analysis for ROE and D/E

\begin{tabular}{lcc}
\hline Correlation t-Statistic Probability & ROE & D/E \\
\hline D/E & -0.427168 & 1.000000 \\
\hline
\end{tabular}

Source: E-views 9 output program

Table 8-2 indicates the correlation analysis shows a moderate inverse relationship between the ROE and $\mathrm{D} / \mathrm{E}$ because of $\mathrm{R}=-0.43$. The $\mathrm{p}<0.05$ proves the connection of significance exists with ROE \& D/E.

The study performs the Ols Regression test using three methods: 
- Common Effect Model or Pooled Least Square (PLS).

- Fixed Effect (FE) Model.

- Random Effect (RE) Model.

Hausman test is a numerical check to identify the best to use, the Fixed Effect or Random Effect model.

- If ( $p>0.05)$ choose Random Effect (RE) Model

- If ( $\mathrm{p}<0.05)$ choose Fixed Effect (FE) Model

Table 9-1. The Ols Regression Hausman test for ROA and D/E

\begin{tabular}{lccc}
\hline Test Summary & Chi-Sq. Statistic & Chi-Sq. d.f. & Prob. \\
\hline Cross-section random & 5.309414 & 1 & 0.0212 \\
\hline
\end{tabular}

Source: E-views 9 output program

Table 9-1 indicates the Hausman test show prob. $=0.0212$ and $\mathrm{p}<0.05$, the most appropriate Regression Model to apply in this case is the (F.E.) Model.

Table 9-2. The Ols Regression Hausman test for ROE and D/E

\begin{tabular}{lccc}
\hline Test Summary & Chi-Sq. Statistic & Chi-Sq. d.f. & Prob. \\
\hline Cross-section random & 45.502142 & 1 & 0.0000 \\
\hline
\end{tabular}

Source: E-views 9 output program

Table 9-2 demonstrates the Hausman test show prob. $=0.0000$ and $\mathrm{p}<0.05$. The most appropriate Regression Model to apply in this case is the (F.E.) Model. The (F.E.) Regression analysis suggests that the dependent variable's link with the independent variables is identical for all Panel Models Estimation.

Table 10-1. Fixed Effect Model (FE) for ROA and D/E

\begin{tabular}{lllll}
\hline Variable & Coefficient & Std. Error & t-Statistic & Prob. \\
\hline $\mathrm{C}$ & 0.033257 & 0.001199 & 27.73926 & 0.0000 \\
\hline $\mathrm{D} / \mathrm{E}$ & -0.001439 & 0.000678 & -2.121595 & 0.0342 \\
\hline
\end{tabular}

Effects Specification

Cross-section fixed (dummy variables)

\begin{tabular}{ll}
\hline R-squared & 0.143327 \\
\hline Prob(F-statistic) & 0.000000 \\
\hline
\end{tabular}

Source: E-views 9 output program

Table 10-1 indicates:

- A weak direct connection of the variables of the model with each other as a whole exists because $\mathrm{R}=\sqrt{ } 0.143327=0.378$. 
- The FE Regression Model is as follows:

$$
\begin{aligned}
& \mathrm{ROA}=\mathrm{C}(1)+\mathrm{C}(2) * \mathrm{D} / \mathrm{E}+[\mathrm{CX}=\mathrm{F}] \\
& \mathrm{ROA}=0.033-0.0014 * \mathrm{D} / \mathrm{E}+[\mathrm{CX}=\mathrm{F}]
\end{aligned}
$$

- The significance of independent variable prob=0.0342 and $\mathrm{p}<0.05$. Thus, H0 is accepted, and $\mathrm{H} 1$ is rejected

H0: numerically substantial independent variables

H1: numerically insignificant independent variables

- Degree of significance regression model is (Prob F-statistic $=0.00<0,05$ ). Thus, the model is numerically substantial (H0 is accepted and $\mathrm{H} 1$ is rejected).

H0: substantial regression analysis

H1: insignificant regression analysis

- The coefficient of determination is R-squared $=14.33 \%$, which means that $14.33 \%$ of ROA changes are due to change in the $\mathrm{CR}$ and $\mathrm{D} / \mathrm{E}$ ratio. The process excluded the remaining $85.67 \%$ of other variables from the estimated model.

The FE Regression Model suggests an identical connection of the dependent variable with the explanatory variables for all Panel Models Estimation.

Table 10-2. Fixed Effect Model (FE) for ROE and D/E

\begin{tabular}{lllll}
\hline Variable & Coefficient & Std. Error & t-Statistic & Prob. \\
\hline $\mathrm{C}$ & 0.234406 & 0.008908 & 26.31421 & 0.0000 \\
\hline $\mathrm{D} / \mathrm{E}$ & -0.098903 & 0.005040 & -19.62283 & 0.0000 \\
\hline
\end{tabular}

Effects Specification

\begin{tabular}{ll}
\hline Cross-section fixed (dummy variables) & \\
\hline R-squared & 0.405361 \\
\hline Prob(F-statistic) & 0.000000 \\
\hline
\end{tabular}

Source: E-views 9 output program

Table 10-2 reveals:

- The moderate direct link between variables of the model as a whole because

$$
\mathrm{R}=\sqrt{ } 0.405361=0.6366 .
$$

- The Fixed Effect FE Regression Model is as follows:

$$
\begin{aligned}
& \mathrm{ROE}=\mathrm{C}(1)+\mathrm{C}(2) * \mathrm{D} / \mathrm{E}+[\mathrm{CX}=\mathrm{F}] \\
& \mathrm{ROE}=0.234-0.099 * \mathrm{D} / \mathrm{E}+[\mathrm{CX}=\mathrm{F}]
\end{aligned}
$$




\section{Macrothink}

International Journal of Accounting and Financial Reporting ISSN 2162-3082 2021, Vol. 11, No. 1

- The significance of independent variable prob=0.00 and $\mathrm{p}<0.05$. Thus, H0 is accepted, and $\mathrm{H} 1$ is rejected.

H0: numerically substantial independent variables

H1: numerically insignificant independent variables

- The significance regression model's degree is (Prob F-statistic $=0.00<0.05$ ) traces statistical significance where $\mathrm{H} 0$ is accepted, and $\mathrm{H} 1$ is rejected.

H0: substantial regression analysis

$\mathrm{H} 1$ : insignificant regression analysis

- Coefficient of determination R-squared $=40.53 \%$. So, $40.53 \%$ of the ROE change is because of the change in $\mathrm{CR}$ and $\mathrm{D} / \mathrm{E}$ ratio. The remaining $59.47 \%$ of the dependent variable changes are consequent to other variables not included in the estimated model.

The Jarque-Bera is a statistical test used to determine if there is a normal distribution of the series or not. This test measures the kurtosis variance and the series's skewness with those of the normal distribution.

The Residuals normal distribution hypothesis is:

H0: Resd. are normally distributed.

H1: Resd. are not normally distributed.

Table 11-1. Jarque-Bera Test of Normality for ROA and D/E

\begin{tabular}{ll}
\hline Skewness & 1.565165 \\
\hline Kurtosis & 15.58682 \\
\hline Probability & 0.000000 \\
\hline
\end{tabular}

Source: E-views 9 output program

Table 11-1 indicates probability $=0.00, \mathrm{H} 1$ is accepted, and $\mathrm{H} 0$ is rejected.

Table 11-2. Jarque-Bera Test of Normality for ROE and D/E

\begin{tabular}{lc}
\hline Skewness & -3.134812 \\
\hline Kurtosis & 62.30546 \\
\hline Probability & 0.000000 \\
\hline
\end{tabular}

Source: E-views 9 output program

Table $11-2$ indicate probability $=0.00, \mathrm{H} 1$ is accepted, and $\mathrm{H} 0$ is rejected.

According to the results, findings indicate $\mathrm{H} 2$ (there is a significant connection of capital structure with firm financial performance) is accepted, then reject the null hypothesis.

H3: firm financial performance holds a significant connection with the stock price. 


\section{Mll Macrothink}

International Journal of Accounting and Financial Reporting

ISSN 2162-3082

2021, Vol. 11, No. 1

The study standardizes the dependent variable stock price SP and the independent variables ROA and ROE by calculating their square root.

Table 12. Descriptive test for rROA, rROE, and rSP

\begin{tabular}{llll}
\hline & rSP & rROE & rROA \\
\hline Median & 6.762396 & 0.362085 & 0.176657 \\
\hline Kurtosis & 7.549374 & 3.842544 & 5.614413 \\
\hline
\end{tabular}

Source: E-views 9 output program

The results of Table 12 indicate the median for the independent variable rROA is 0.18 , the median for the independent variable rROE is 0.36 , and the median for the dependent variable $\mathrm{rSP}$ is 6.76. Results also indicate Kurtosis for the independent variable rROA is 5.61, Kurtosis for the independent variable rROE is 3.84, and Kurtosis for the dependent variable $\mathrm{rSP}$ is 7.55 .

Table 13. Correlation analysis for rROA, rROE, and rSP

\begin{tabular}{llcl}
\hline & \multicolumn{1}{c}{ rSP } & rROE & rROA \\
\hline rSP & 1.000000 & & \\
\hline rROE & 0.064678 & 1.000000 & \\
\hline rROA & 0.139724 & 0.405280 & 1.000000 \\
\hline
\end{tabular}

Source: E-views 9 output program

In Table 13, rSP demonstrates a weak direct relationship with rROE because $\mathrm{R}$ is approx. 0.065. The results also reveal a weak direct connection of rSP with rROA because $\mathrm{R}$ is approx. 0.14 . The $\mathrm{p}<0.10$ means a significant relationship between all variables exists.

The study performs the Ols Regression test using three methods:

- Common Effect Model or Pooled Least Square (PLS).

- Fixed Effect (FE) Model.

- Random Effect (RE) Model.

Hausman test is a numerical check to identify which is best to use the Fixed Effect or Random Effect model.

- If ( $p>0.05)$ choose Random Effect (RE) Model

- If ( $\mathrm{p}<0.05)$ choose Fixed Effect (FE) Model

Table 14. The Ols Regression Hausman test for rROA, rROE and rSP

\begin{tabular}{lccc}
\hline Test Summary & Chi-Sq. Statistic & Chi-Sq. d.f. & Prob. \\
\hline Cross-section random & 0.192709 & 2 & 0.9081 \\
\hline
\end{tabular}

Source: E-views 9 output program 


\section{Ml Macrothink}

International Journal of Accounting and Financial Reporting

ISSN 2162-3082

2021, Vol. 11, No. 1

The results of table 14 indicate the Hausman test show prob. $=0.9081$ and $p>0.05$. The most appropriate Regression Model to apply in this case is the (RE) Model.

Table 14-1. The Ols Regression Hausman test for rROA, rROE, and rSP

\begin{tabular}{ll}
\hline Cross-section random effects - R-squared & 0.040798 \\
\hline Cross-section fixed - R-squared & 0.808554 \\
\hline
\end{tabular}

Source: E-views 9 output program

However, $\mathrm{R}^{2}=0.04$, and cross-section random effects are weak. The regression analysis considers the FE model because of the higher worth of $\mathrm{R}^{2}$ that is approx. 80\%, as shown in Table 14-1. The Regression analysis presumes an identical connection of the dependent variable with the explanatory variables for all Panel Models Estimation.

Table 15. Fixed Effect (F.E.) Model for rROA, rROE, and rSP

\begin{tabular}{lcccc}
\hline Variable & Coefficient & Std. Error & t-Statistic & Prob. \\
\hline $\mathrm{C}$ & 6.839250 & 0.461861 & 14.80804 & 0.0000 \\
\hline rROE & 3.550798 & 1.022807 & 3.471619 & 0.0006 \\
\hline rROA & 4.584270 & 2.695538 & 1.700688 & 0.0895 \\
\hline
\end{tabular}

Effects Specification

Cross-section fixed (dummy variables)

\begin{tabular}{ll}
\hline R-squared & 0.808554 \\
\hline Prob(F-statistic) & 0.000000 \\
\hline
\end{tabular}

Source: E-views 9 output program

Table 15 indicates:

- The moderate direct connection between the model variables as a whole because

$R=\sqrt{ } 0.81=0.89$.

- The Fixed Effect FE Regression Model is as follows:

$\mathrm{RSP}=\mathrm{C}(1)+\mathrm{C}(2) * \mathrm{RROE}+\mathrm{C}(3) * \mathrm{RROA}+[\mathrm{CX}=\mathrm{F}]$

$\mathrm{RSP}=6.839+3.550 * \mathrm{RROE}+4.584 * \mathrm{RROA}+[\mathrm{CX}=\mathrm{F}]$

- The significance of independent variables $\mathrm{prob}=0.00$ and $\mathrm{p}<0.1$. Thus, the study accepts $\mathrm{H} 0$ and rejects $\mathrm{H} 1$.

H0: numerically substantial independent variables

H1: numerically insignificant independent variables

- Degree of significance regression model is (Prob F-statistic $=0.00<0.05$ ). So, there is statistical significance in the model ( $\mathrm{H} 0$ accepted and $\mathrm{H} 1$ is rejected).

H0: regression analysis substantial 
H1: regression analysis insignificant

- Coefficient of determination R-squared $=80.85 \%$. So, $80.85 \%$ of ROE changes result from the change in $\mathrm{CR}$ and $\mathrm{D} / \mathrm{E}$ ratio. The remaining $19.15 \%$ is because of additional factors excluded from the estimated model.

The Jarque-Bera is a statistical test used to determine if there is a normal distribution of the series or not. This test measures the variance in the kurtosis and skewness of the series with those of the normal distribution

The Residuals normal distribution hypothesis is:

H0: Resd. normally distributed.

H1: Resd. not normally distributed.

Table 16. Jarque-Bera Test of Normality for rROA, rROE, and rSP

\begin{tabular}{ll}
\hline Skewness & 1.024899 \\
\hline Kurtosis & 6.935506 \\
\hline Probability & 0.000000 \\
\hline
\end{tabular}

Source: E-views 9 output program

Accordingly, the results of table 16 indicate probability $=0.00$. So, the study accepts $\mathrm{H} 1$ and rejects $\mathrm{H} 0$.

According to the results, findings indicate $\mathrm{H3}$ (firm financial performance has a significant relationship with the stock price) is accepted and reject the null hypothesis.

The study applied the pooled regression, the fixed effect plus random effect techniques with the panel data analysis. Consistent with the statistical results, findings indicate liquidity and capital structure impact firm financial performance, where the capital structure has a higher impact, and firm financial performance impact stock price. That is to say, we accept $\mathrm{H} 1, \mathrm{H} 2$, and $\mathrm{H} 3$ and reject the null hypothesis.

\section{Conclusion and Future Studies}

The compatibility with the study's statistical outcomes as presented, the findings specify that liquidity and capital structure impact the technology firm's financial performance. The capital structure has a higher impact, and a technology firm's financial performance affects its stock price. Based on these findings, the study suggests that a greater variety of factors with a significant positive impact on technology firm financial performance is needed to guarantee the technology firm's internal health and wealth, hence maintaining a more competitive national and international market presence.

This study's results cannot be generalized because it is confined only to the technology and innovation sector. This study was made right before the COVID 19 pandemic, which made it very difficult to obtain complete and more diverse data from other industries on a timely basis. Thus, recommended future studies may include: (1) Increasing the number of 


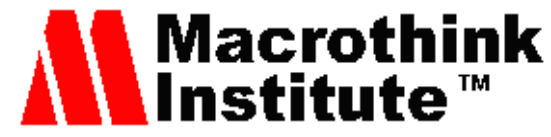

International Journal of Accounting and Financial Reporting ISSN 2162-3082

independent variables that might affect technology firm financial performance and stock price. (2) including a more diverse sample so the results can be generalized. (3) focusing on the three fiscal years 2019-2021 (before, during, and after the lockdown because of the COVID19).

The limitations of this study open the door for further research work in this area. It is worth applying this same study to firms in other sectors during the three fiscal years 2019-2021. It is worth identifying the benefits of the COVID19 global pandemic on the technology and innovation sector to help interested parties maximize their profits and develop and maintain a competitive advantage according to the new conditions injected into the business environment. Studying the advantages and disadvantages of COVID19 in the other sectors is worth noting as well.

\section{References}

Ahmad, N., Salman, A., \& Shamsi, A. (2015). Impact of financial leverage on firms' profitability: An investigation from cement sector of Pakistan. Research Journal of Finance and Accounting, 6(7), 2222-1697.

Appiadjei. (2014). Capital structure and firm performance: Evidence from Ghana stock exchange. Research Journal of Finance and Accounting, 5(16), 37-43.

Asiri, \& Hameed. (2014). Financial ratios and firm's value in the Bahrain Bourse. Research Journal of Finance and Accounting 5(7), 1-9.

Basit, A., \& Hassan, Z. (2017). Impact of capital structure on firms performance: a study on Karachi Stock Exchange (KSE) listed firms in Pakistan. International Journal of Management, Accounting and Economics, 4(2), 118-135.

Bibi, N., \& Amjad, S. (2017). The relationship between liquidity and firms' profitability: A case study of Karachi Stock Exchange. Asian Journal of Finance \& Accounting, 9(1), 54-67.

Borhan, H., Mohamed, R. N., \& Azmi, N. (2014). The impact of financial ratios on the financial performance of a chemical company. World Journal of Entrepreneurship, Management and Sustainable Development.

Cole, C., Yan, Y., \& Hemley, D. (2015). Does capital structure impact firm performance: An empirical study of three U.S. sectors. Journal of Accounting and Finance, 15(6), 57.

Devi, A., \& Devi, S. (2014). Determinants of firms' profitability in Pakistan. Research Journal of Finance and Accounting, 5(19), 87-91.

Dioha, C., Mohammed, N. A., \& Okpanachi, J. (2018). Effect of firm characteristics on profitability of listed consumer goods companies in Nigeria.

Durand, R., \& Coeurderoy, R. (2001). Age, order of entry, strategic orientation, and organizational performance. Journal of business venturing, 16(5), 471-494. 


\section{MInstitute Macrothink $_{\text {Int }}$}

International Journal of Accounting and Financial Reporting ISSN 2162-3082

Ehiedu, V. C. (2014). The impact of liquidity on profitability of some selected companies: The financial statement analysis (FSA) approach. Research Journal of Finance and Accounting, 5(5), 81-90.

Hann, R. N., Kim, H., Wang, W., \& Zheng, Y. (2020). Information Frictions and Productivity Dispersion: The Role of Accounting Information. The Accounting Review, 95(3), 223-250.

Khan, A. G. (2012). The relationship of capital structure decisions with firm performance: A study of the engineering sector of Pakistan. International Journal of Accounting and Financial Reporting, 2(1), 245-262.

Kim, Y., Su, L., Wang, Z., \& Wu, H. (2020). The Effect of Trade Secrets Law on Stock Price Synchronicity: Evidence from the Inevitable Disclosure Doctrine. The Accounting Review, 0000-0000.

Kimondo, C. N., Irungu, M., \& Obanda, M. (2016). The impact of liquidity on the financial performance of the non-financial firms quoted on the Nairobi Securities Exchange. Researchjournali's Journal of Accounting, 4(2), 1-12.

MacCarthy, J., \& Ahulu, H. (2019). Does capital structure affects firms' performance in Ghana? Panel data analysis. Panel Data Analysis (October 14, 2019).

Mauwa, J., Namusonge, G. S., \& Onyango, S. (2016). Effect of capital structure on financial performance of firms listed on the Rwanda Stock Exchange. European Journal of Business, Economics and Accountancy, 4(4), 1-11.

Modigliani, F., \& Miller, M. H. (1958). The cost of capital, corporation finance and the theory of investment. The American economic review, 48(3), 261-297.

Mudambi, R., \& Nicosia, C. (1998). Ownership structure and firm performance: evidence from the U.K. financial services industry. Applied Financial Economics, 8(2), 175-180.

Mwangi, L. W., Makau, M. S., \& Kosimbei, G. (2014). Relationship between capital structure and performance of non-financial companies listed in the Nairobi Securities Exchange, Kenya. Global Journal of Contemporary Research in Accounting, Auditing and Business Ethics, 1(2), 72-90.

Nassirzadeh, F., \& Rostami, A. (2010). Studying the relationship between liquidity indices (traditional and modern) and the profitability of companies listed in Tehran Stock Exchange. Accounting and Auditing Review, 98511, 1-17.

Navleen, K., \& Jasmindeep, K. (2016). Determinants of profitability of automobile industry in India. Journal of Commerce and Accounting Research, 5(3).

Omondi, M. M., \& Muturi, W. (2013). Factors affecting the financial performance of listed companies at the Nairobi Securities Exchange in Kenya. Research Journal of Finance and Accounting, 4(15), 99-104.

Padrón, Y. G., Apolinario, R. M. C., Santana, O. M., Martel, M. C. V., \& Sales, L. J. (2005). Determinant factors of leverage. The Journal of Risk Finance. 


\section{Ml Macrothink}

International Journal of Accounting and Financial Reporting

ISSN 2162-3082

Peyravan, L. (2019). Financial Reporting Quality and Dual-Holding of Debt and Equity. The Accounting Review, 0000-0000.

Pham, C. D., Tran, Q. X., \& Nguyen, L. T. N. (2018). Effects of Internal Factors on Financial Performance of Listed Construction-Material Companies: The Case of Vietnam. Research Journal of Finance and Accounting, 9(10).

Taani, K. (2013). The relationship between capital structure and firm performance: evidence from Jordan. Global Advanced Research Journal of Management and Business Studies, 2(11), 542-546.

Tharmila, K., \& Arulvel, K. K. (2013). The impact of the capital structure and financial performance: A study of the listed companies traded in Colombo stock exchange. Merit Research Journal of Accounting, Auditing, Economics and Finance, 1(5), 106-117.

Tzelepis, D., \& Skuras, D. (2004). The effects of regional capital subsidies on firm performance: an empirical study. Journal of Small Business and Enterprise Development.

Umar et. al. (2012). Impact of capital structure on firms' financial performance: Evidence from Pakistan. Research Journal of Finance and Accounting 3(9), 1-12.

Utami, M. R., \& Darmawan, A. (2019). Effect of DER, ROA, ROE, EPS and MVA on stock prices in Sharia Indonesian stock index. Journal of Applied Accounting and Taxation, 4(1), $15-22$.

Weber, D. P., \& Yang, Y. S. (2020). The debt-equity choice when regulatory thresholds are based on equity values: Evidence from SOX 404. The Accounting Review, 95(2), 339-364.

Zeitun, R., Temimi, A., \& Mimouni, K. (2017). Do financial crises alter the dynamics of corporate capital structure? Evidence from GCC countries. The Quarterly Review of Economics and Finance, 63, 21-33.

\section{Copyright Disclaimer}

Copyright for this article is retained by the author(s), with first publication rights granted to the journal.

This is an open-access article distributed under the terms and conditions of the Creative Commons Attribution license (http://creativecommons.org/licenses/by/4.0/) 